\title{
Contextualizing alternative development perspectives in local governance systems and communities of Nepal
}

\author{
Sanjeeb Ghorasainee * \\ Graduate School of Global Governance, Meiji University, Tokyo, Japan
}

\author{
Keywords \\ Social capital \\ Assets \\ Nepal \\ Community development \\ Local governance
}

Received: 7 October 2019

Accepted: 8 November 2019

Published: 23 December 2019

\begin{abstract}
From a centralized state, Nepal adopted federalism in 2015 and local level elections were held in 2017, after twenty years since the last local election. In this light, this study aims to explore how alternative theories and models of rural community development could operate in the new system. An extensive review of literature on this field was done to understand the focal concepts and their relationships. It was followed by document analysis to contextualize these concepts by understanding local governments' local systems and settings in Nepal. This research suggests that heterogeneity in Nepalese communities has had its effects on social capital accumulation and effective participation. It also found that the lack of meaningful interaction between marginalized rural communities and public institutions has limited their economic opportunities and development capacity. However, with institutional arrangements of inclusive representation, affirmative action, and other policy measures adopted in the new system of governance as guaranteed by the new constitution's provisions, foundations have been laid to increase the stock of bridging social capital and promote community action. Furthermore, with the emergence of new leaders elected in the local level election of 2017 and other informal community leaderships, a 'mediating agency' is identified to link communities and public institutions and mobilize local assets to create economic opportunities through their linking ties.
\end{abstract}

(C) 2019 The Author(s). Published by TAF Publishing

\section{INTRODUCTION}

Nepal is listed in the group of least developed countries (United Nations, 2018). Despite having abundant natural resources, young workforce and big tourism potential, being considered among the poorest countries in the world is an irony. Economic growth has not been at a satisfactory rate and the country was characterized by political transition and instability in recent decades. Nepal went through a decade of internal conflict, which ended in 2006. The conflict took the lives of seventeen thousand people and made huge damage to public properties and infrastructures.

The development process took a halt and youth started fleeing the country to become immigrant workers abroad in search of jobs. Nepal's two giant neighbors, India and China are growing exponentially, and Nepal has failed to match them or take big advantage from them. According to the economic survey conducted by Ministry of Finance (2019), the average annual economic growth rate of Nepal in the last decade has only been 4.6 percent. The same survey also found that preceding decade was even worse with only 2.2 percent average growth rate, due to the internal conflict. The internal conflict and sluggish growth is largely attributed to the economic and socio-cultural inequality fueled by heavily centralized government system that was ineffective to practice good governance and provide service delivery (Lawoti \& Pahari, 2009).

Nepal is a country demographically heterogeneous and geographically diverse. It is a multi- ethnic, multi-lingual and multi-religious country. The majority of the population lives in rural areas, and about 70 percent are dependent on agriculture. Despite that, the contribution of agriculture sector to the national GDP of Nepal is only 27 percent and the aver-

\footnotetext{
* corresponding author: Sanjeeb Ghorasainee

†email: sanjgh09@gmail.com
} 
age annual growth rate of agriculture sector has only been 3.1 percent over the last decade (Ministry of Finance, 2019). This suggests that a lot needs to be done to either improve the productivity of this sector or create employment and viable livelihood opportunities in secondary or tertiary sectors of the economy.

However, the traditional practice of a heavily centralized governance formulating top-down development policies, couldn't generate active participation and develop ownership from marginalized groups and rural communities. There is an urgent need to break free from the shackles of failure of government programs in yielding desired outcomes and prevent valuable resources being used unproductively. It is in this light that the development discourse of Nepal has been shifting from traditional to more recent alternative theories and models of development.

With the transformation of Nepal into a federal democratic republic from a centralized state through promulgation of a new constitution in 2015, it has embarked on a new path of governance, development and progress. Local bodies have new leaders elected from the local level election of 2017 that took place after twenty years since the last local election. Hence, the major attention has now shifted from political activism to more towards socio-economic development. Long awaited political stability can be seen and therefore increasing emphasis is on adoption of newer models of development for faster growth and development. This has coincided with a general trend in the development fraternity of shifting focus from traditional and conventional approaches to studying development, to viewing it from alternative perspectives. Social capital and assets based community development approach are alternative theories and approaches that are prominent in this regard.

This research thus seeks to identify the focal concepts of these alternative perspectives and understand their relationships, through review of existing literature. It then aims to contextualize these concepts in the local systems and settings of Nepal and explore how such theories and models could operate in the new system of local governance to develop rural communities in Nepal. Considering that the new system of local governance is only in practice since 2017 and the newly formed local governments are at their learning stages, this research aims to provide novel contribution by identifying the foundations laid by the new constitution of Nepal and systems in place for such alternative ideas to operate. This study therefore is significant and especially timely to provide an added perspective to the local governance knowledge and practice in Nepal.

\section{LITERATURE REVIEW}

Shift Towards Alternative Development Theories and Approaches

The traditional top-down models of development relied heavily on central governments and aid agencies to play major role in formulating development programs and policies and implementing it to meet the needs or solve problems being faced by the rural communities. Such centrally planned top-down heavy initiatives required less involvement or participation from the people and therefore they were regarded as passive recipients or 'clients' and not a role fulfilling 'citizen' (Mathie \& Cunningham, 2003). External actors such as aid agencies and I/NGOs came to communities and surveyed about the deficiencies there, identified the perceived needs of the communities and prescribed the solutions they could offer to solve the problems existing there.

Escobar (1995) critiqued the top-down model as disempowering to the local people and pointed that these were a failure due to local people not taking ownership, but rather making them always look towards outsiders for help. He said that the consequences of a top-down heavy development approach without effective local participation would be counterproductive. There is a fear that such an approach promotes dependency on outsiders and community members become passive in their own development efforts. Increased dependency on outsiders leads to weakening social ties among members of the community due to less interaction and that will have damaging effects on the neighbor relationship, as "the glue that binds communities together is weakened" (Kretzman \& McKnight, 1993; Punluekdej \& Srisorn, 2017). Haines (2014) further states that the needs based top-down projects mainly looked for existing problems. However, if they focused on problems, causes were often overlooked and if they looked to address the causes, they were too 'overwhelming'. For example, providing solutions to root causes such as poverty or unemployment is too big a task for a single community. Therefore, aiming to provide solutions to such issues may lead to the creation of 'unreasonable expectations' and failure to achieve that leading to 'disappointments' (Haines, 2014). Furthermore, such projects also attracted criticisms for being hugely dependent on external actors who work for various organizations such as national and international non-governmental, nonprofit organizations and multilateral aid agencies. Out of the valuable resources meant for providing services to people, a considerable portion of it went to administrative and overhead costs i.e. paying the staffs and maintaining the cost of operation which have also raised questions on effi- 
ciency and effectiveness of such organizations (Cuyugan et al., 2017; Burkart, Wakolbinger, \& Toyasaki, 2018; Haines, 2014).

\section{Assets Based Community Development}

Kretzman and McKnight (1993) challenged the idea that local communities were incapable of addressing their problems. Hence, they developed a bottom-up alternative, Assets Based Community Development (ABCD) approach. This approach diverted the attention of people towards a more empowering idea where people could identify and mobilize their existing assets available within local communities to solve collective problems of the community. Such bottom-up approach combined with external assistance according to findings of Nikkhah and Redzuan (2009), foster participation and empower the community, which ultimately leads to sustainable development outcomes. On the contrary, they found that top-down approaches limited participation and therefore not significantly empower the community to lead to sustainable development.

In order to identify existing assets in the community, members can develop an Assets Map, which enlists assets present in the community in the form of physical resources, talents or skills of individuals, their associations with one another and the formal institutional arrangements in the community (Green, 2014). ABCD thus is very useful to locate untapped and unidentified local assets, mobilize and connect these assets to solve community problems or work for collective advancement of the community. ABCD recognizes that assets are multifunctional and therefore, choices need to be made on how it should be used. They can be used in consumption, but at the same time be used in production to create value added outputs (Green \& Haines, 2015). By concentrating on assets present in the community, (Haines, 2014) argues it creates a positive snowball effect that will create an influence in other areas of the community, including addressing its problems and needs.

$\mathrm{ABCD}$ approach, "particularly draws attention to social assets: the particular talents of individuals, as well as the social capital inherent in the relationships that fuel local associations and informal networks" (Mathie \& Cunningham, 2003). This is in line with the belief of Kretzman and McKnight (1993) that, local people's capacities and their associations form the basis of a strong and powerful community. Therefore, not only does it consider the natural resources or the physical and financial capital present in the community as valuable but the formal and informal network of social ties are considered to be valuable too. These ties among individuals, associations and organizations present in the community known as social capital, foster avenues for partnership and community mobilization.

\section{Social Capital}

Theories on social capital have taken prominence in various disciplines ranging across economics, sociology and in recent times to disaster research and community development. Coleman (1988) identified social capital as a parallel with other identified capitals such as financial, physical and human capital. He stated that relationships within the family and outside of it in the community had considerable value. Adding to this research, Gittell and Vidal (1998) introduced the bonding and bridging social capital concepts in community organizing. Distinction was made on the nature of relationships between individuals and associations in the community. Bonding social capital is the nature of connection within members of similar social groups and communities who are characterized by demographic similarity. Examples include relationships within families, kinships, neighbors, people from same race, ethnicity, etc. On the other hand, bridging social capital is a connection between members belonging to different race, ethnicity, socioeconomic status, etc. (Putnam, 2000; Woolcock \& Narayan, 2000). Fukuyama (2002) further states that bridging social capital increases the 'radius of trust' from just family or kinship to wider society through interaction.

Following the aforementioned two distinctions, scholars have added another distinction of social capital as linking social capital. The concept of linking social capital is about the relationship between individuals, organizations and institutions lying in a different hierarchy of power. Recent studies about linking social capital can be seen centered around the network of relationship between people, community and formal institutions or in other terms between citizen and those in power (Aldrich \& Meyer, 2015; Minamoto, 2010; Woolcock, 2001). The key distinction between bridging social capital and linking social capital is the nature of connection among networks. Claridge (2018) states that bridging social capital is a horizontal relationship with different social groups, whereas linking social capital is a vertical relationship with institutions and those in different status of power.

In his research on the role of social capital in disaster recovery Daniel Aldrich found that social capital played a vital role in the building of resilient communities and "overcoming of barriers to collective action" (Aldrich \& Meyer, 2015). He found that areas characterized with higher social capital could mobilize their residents to participate and recover 
quickly. Alesina and La Ferrara (2000) also argue that social ties from both formal and informal networks in the community are vital to build their capacities and influence policymakers to gain access to economic resources. Such investments made by use of bridging and linking social capital present in local social networks according to Aldrich and Meyer (2015), are cheaper yet more efficient, effective and have better sustainable impacts than compared to interventions only focused on physical infrastructures.

Hence, scholars in the fields of both social capital and assets-based approach to community development emphasize the importance of local social networks and use of it to maximize socio-economic gains for individuals, communities and nation as a whole. By identifying local assets and using the networks in the community to connect and mobilize, communities can build their capacities and improve their livelihood through the creation of better economic opportunities.

Mathie and Cunningham (2003) argued that through mobilization of bonding social capital and enhancement of bridging social capital, local economic opportunities could be developed. They state, "ABCD is a practical application of the concept of social capital" (Mathie \& Cunningham, 2003). Woolcock and Narayan (2000) too point out that increasing the stock of bridging social capital of the poor is important to build their capacity. Linking the poor and marginalized to institutions and power is of an utmost significance for them to be able to utilize their local assets and turn them into productive economic outcomes.

\section{Participation, Heterogeneity and Social Capital}

Chambers (1983) advocated participatory development as a key to development of poor communities. He argued that participation is key for inclusion of poor into decisionmaking. Mansuri and Rao (2004) believe this enables incorporation of local ideas into development projects, better design and effective monitoring of development activities. To encourage participation in development activities and to build community capacity, interventions for development of human resources, leadership, organizations and existing social networks must be done (Chaskin, Brown, Venkatesh, \& Vidal, 2001). More recent advocates of engaging people into development practice, voice for adoption of more empowering and more meaningful participation strategies. Traditional participation strategies limiting to informing and consulting, in their view, do not empower people as desired (Nikkhah \& Redzuan, 2009; Ross, Baldwin, \& Carter, 2016). Strategies such as co-production, are believed to empower people and give them central position in development planning and practice. The degree to which power is diffused to people and their levels of participation in designing, implementing and evaluating programs considerably vary as compared to traditional strategies of participation. Krishna (2002) proposes an efficient way to create and build social capital in a relatively less period of time. That is through an engagement of state in "co-producing services alongside community groups, made more effective by public investments in social capital" (Krishna, 2002). Michael B. Marks, links co-production to social capital and asset-based approach to further illustrate the significance of co-production in community activities. He states:

"Coproduction is an asset-based approach that rewards contributions and alters the notion of work within human service programs and in communities. Its core principle of reciprocity aims to expand the benefits of co-production activities from individuals, to organizations, to groups of organizations and to neighborhoods and communities" (Marks, 2008).

The co-production framework enables people to participate in service delivery and not just remain as passive beneficiaries of services. People are seen as important resources, contributors and agents for change to build local communities (Mansuri \& Rao, 2012).

However, strategies such as co-production and assets based approach to build and utilize the social capital have challenges in heterogeneous communities. Various researches on heterogeneity have concluded that it has its effect on social capital formation and ultimately on the level of participation. Alesina and La Ferrara (2000) argue that social capital formation is weak in economically unequal, racially and ethnically heterogeneous societies because people have more trust and are more comfortable among people belonging to the similar economic group, race or ethnicity. Thus, people are more connected among people of their own caste or kinship. This claim is also supported by Lin (2000), who found evidences from research that showed varying amounts of social capital or access to resources across gender, race and ethnicity based on the structural position they occupy and what their associated networks were in the society. It was found that social networks of women and minorities were "deficient in resources or in social capital" (Lin, 2000). A disadvantaged group would mostly have networks with members belonging to the same group and hence their network would be deficient in social capital as compared to other privileged groups. Coffé and Geys (2006) carried out a study at local government level and found that ethnic heterogeneity had significant negative effects on social capital formation. 
Woolcock (2001) further found out that in heterogenous communities, having few predominant caste and ethnicities over numerous minority groups is problematic, if the public institutions are weak. However, he also states that diversity could be an asset if certain preconditions are fulfilled. Strong institutional arrangements to address the inclusion of diverse ethnic minorities and measures to promote bridging activities between heterogeneous communities could lead to effective community participation and ultimately development of their capacities. Alesina and Ferrara (2005) also suggest that diversity could lead to more productive outcomes if different skills of heterogeneous groups are complementary to each other. This will contribute to avoid conflicts and disagreements. Hence measures to bridging social network and cooperation among heterogeneous groups are vital to achieving active participation through strong institutional arrangements with inclusive representation.

For economic growth and development of communities, (Woolcock \& Narayan, 2000) state that "the nature and extent of the interactions between communities and institutions hold the key to understanding the prospects for development". Hence communities without meaningful interaction with state institutions lack behind and fail to easily access state services. To tackle this crisis in relation, local leadership plays an important role as a mediating agency between communities and state and also transforms the static social capital present within the communities into an active social capital (Krishna, 2002). The active social network can then identify local assets and mobilize it for community development by creating local economic opportunities.

\section{METHODS}

In order to achieve the objectives of this research, extensive review of existing literature was done on assets based approaches to community development and social capital. Data and information were gathered through secondary sources such as books, academic journals, and other scholarly literature from prominent scholars and practitioners in these fields. They were reviewed to identify and build a deeper understanding of the focal concepts and their relationships.

Document analysis followed the literature review stage to gain an insight into the ground reality of Nepal's local governance systems and rural communities. Bowen et al. (2009) states that document analysis is helpful in contextualizing research in one's field, as documents provide relevant data and background information on the subject. He further claims that when the main evidence in an enquiry is constituted within documents, this method is suitable. The Constitution of Nepal 2015, was the most important document in order to understand the local systems, contexts and institutional arrangements. This was because the constitutional provisions form the basis for local governance in Nepal and hence this document was a comprehensive tool for secondary information. Socio-economic and demographic information on Nepal was gathered through statistical data from published official documents from various sources of government of Nepal, reports from national and international agencies and organizations working in the field of development in Nepal. The experience of author himself having grown up observing and studying the rural communities of Nepal was an important asset for analysis too.

Thus, understanding developed on focal concepts of assets based community development and social capital theory and their relationships from review of existing literature, are contextualized in the local settings and systems of Nepal through document analysis. Furthermore, measures through which these concepts could operate in the local contexts for development of rural communities is explored.

\section{RESULTS}

\section{Understanding the Local Context}

The geographic as well as the demographic composition of Nepal is diverse and heterogeneous. The country can be topographically divided into high mountains in the North, hills in the centre and plain lands of Terai in the South. The altitude ranges from the lowest point of 70 meters above sea level to the summit of Mount Everest at 8848 meters, the highest point on earth. Therefore, the climate in Nepal ranges from tropical one in the south to Alpine regions on the Himalayas in the north. Depending upon the zone and altitude, there are contrasting differences on the plant and animal bio-diversity and lifestyle of people living there. Such diversity in a small country like Nepal with an average north-south distance of only 200 Kilometers is unique.

People living in each of these regions are from diverse caste, ethnicities and socio-economic backgrounds. According to the last national census carried out by the Central Bureau of Statistics (CBS) of Nepal, the total population of Nepal is 26.5 million. There are 125 ethnic and caste groups, 123 languages spoken as mother tongue and up to 10 identified religious affiliations. Hindu is the major religion practiced by 81.34 percent of the population. Other major religions that are followed are, 9.04-percent Buddhism, 4.39-percent Islam, 3.05-percent Kirat and 1.42-percent 
Christianity. Nepali is the most spoken language with 44.6 percent of the population speaking it as a mother tongue. Other major languages spoken are Maithali (11.7\%), Bhojpuri (6\%), Tharu (5.8\%), Tamang (5.1\%), Newar (3.2\%) etc (Central Bureau of Statiscs, 2019).

Many indigenous ethnic groups such as Madhesi and Tharu, caste groups such as Dalits and minorities such as Chepang and Raute have been marginalized and have in recent times started activism for their inclusion in state institutions. People from remote rural areas and villages too have voiced their concern for lack of access to government services. In this context, addressing diverse aspirations from heterogeneous groups for their socio-economic development and achieving inclusive development through coordinated part- nerships and active participation is a difficult challenge.

\section{Caste, Ethnicity and Inclusion}

Nepalese communities have some predominant caste and ethnic groups exercising more power and access to resources over fragmented and marginalized minorities. The high caste Brahmin-Hill and Chhetree are considered as ruling groups who constitute about 31 percent of the total population (Central Bureau of Statiscs, 2014). Eastern Mountain and hill areas have Limbu and Rai as predominant groups. Terai also has some predominant castes and ethnicities. Brahmin-Hill, Yadav and Tharu castes are predominant in Eastern, Central and Western Terai respectively. Table 1, below, shows the predominant caste groups present in different regions of Nepal.

TABLE 1. Predominant caste groups in different regions of Nepal (Source: Central Bureau of Statiscs (2014)

\begin{tabular}{ll}
\hline \hline Area of Nepal & Predominant Caste \\
\hline Eastern Mountain & Limbu \\
Eastern Hill & Rai \\
Eastern Terai & Brahmin-Hill \\
Central Mountain & Tamang \\
Central Hill & Tamang \\
Central Terai & Yadav \\
Western Mountain & Gurung, Chhetree \\
Western Hill & Brahmin-Hill, Chhetree \\
Western Terai & Tharu, Brahmin-Hill \\
\hline \hline
\end{tabular}

Various social problems have unfortunately deep rooted into the society due to such social divisions. The practice of the Caste System, where people belonging to a so-called low caste called as Dalit are considered untouchables, and various discrimination based on color, gender etc. are few to name. The Constitution of Nepal 2015 therefore, on the legal front, regards any discrimination in the name of caste and ethnicity as a punishable crime. It has also guaranteed other provisions to address the aforementioned problems by formulating various commissions representing the oppressed, marginalized and minority groups with mandates to work for their empowerment. Some examples include National Dalit Commission, National Inclusion Commission and National Women Commission among others who have started work for the benefit of low caste groups, marginalized communities and women respectively.

The constitution also directs the Election Commission to hold election under a mixed electoral system. 60\% members of the 275-member parliament are elected under first past the post system or directly by the people. Remaining $40 \%$ are chosen through proportional representation system by political parties based on the votes each party get
(Government of Nepal, 2015). Political parties then choose their representatives proportionately from different gender, religion, caste and ethnicity and minority communities. The constitution also guarantees the provision of at least one-third women representation from each political party in the parliament. Hence, Effective implementation of these institutional arrangements is aimed to promote acceptance of heterogeneity and celebration of diversity. However, effective implementation to bring into the mainstream these marginalized and oppressed groups, and make linkage to state institutions for good governance remains a challenge as these groups have not had their appropriate representation or experience of being in the mainstream, historically.

\section{Local Governance and Representation}

Rural communities in Nepal were deprived of fruitful interactions with state institutions. Governance was heavily centralized and hence people in remote parts of the countries were deprived of basic services such as access to quality education and healthcare among others. A decade of Maoist insurgency from 1996 to 2006 further crippled the governance and local bodies remained without elected leaders for 
two decades. Since the local level election of 1997, it took 20 years to hold the next election of local bodies. The last local level election in Nepal was held in 2017, after promulgation of the new constitution in 2015 that had guaranteed the provision of restructuring the country into new administrative divisions under federal structure.

Previously, at the local level, Nepal was divided into 75 districts, 3157 villages, and 217 municipalities. However, governance remained very centralized and devolution of power to local bodies wasn't adequate as major decisionmaking authority weren't in the hands of the local bodies. After much deliberation and debate between political parties, various committees formed for state restructuring and other stakeholders, it was finally agreed to divide Nepal into 7 federal provinces, 77 districts and 753 local bodies. The local bodies comprise of 6 metropolitan cities, 11 submetropolitan cities, 276 municipalities and 460 rural municipalities (Ministry of Finance 2019, 13). The new administrative divisions are formed in consideration of the population distribution, geography, language, culture, available natural resources, and community structure among other factors (Government of Nepal, 2015).
Before the local election of 2017, the local levels were without elected representatives for nearly 2 decades. Civil servants were chosen as executive officers and given the power and authority to run the local level. The legislative function of local levels was non-existent and executive orders were made by the central government. However, with the promulgation of a new constitution and the successful completion of the local level election, local bodies now have their elected representatives. Article 57 of the Constitution of Nepal 2015 states that the local government will assume both legislative and executive function. The executive body shall exercise the power of implementing local governance while the assembly exercises legislative power (Government of Nepal, 2015).

The representation system in local governments is mixed, meaning people directly elect some leaders while assemblymen elect the others with a 'quota' arrangement for some members to be elected from Dalit or minority communities. Figure 1 below, shows the composition of Municipal Assembly (Municipality) and Village Assembly (Rural Municipality).
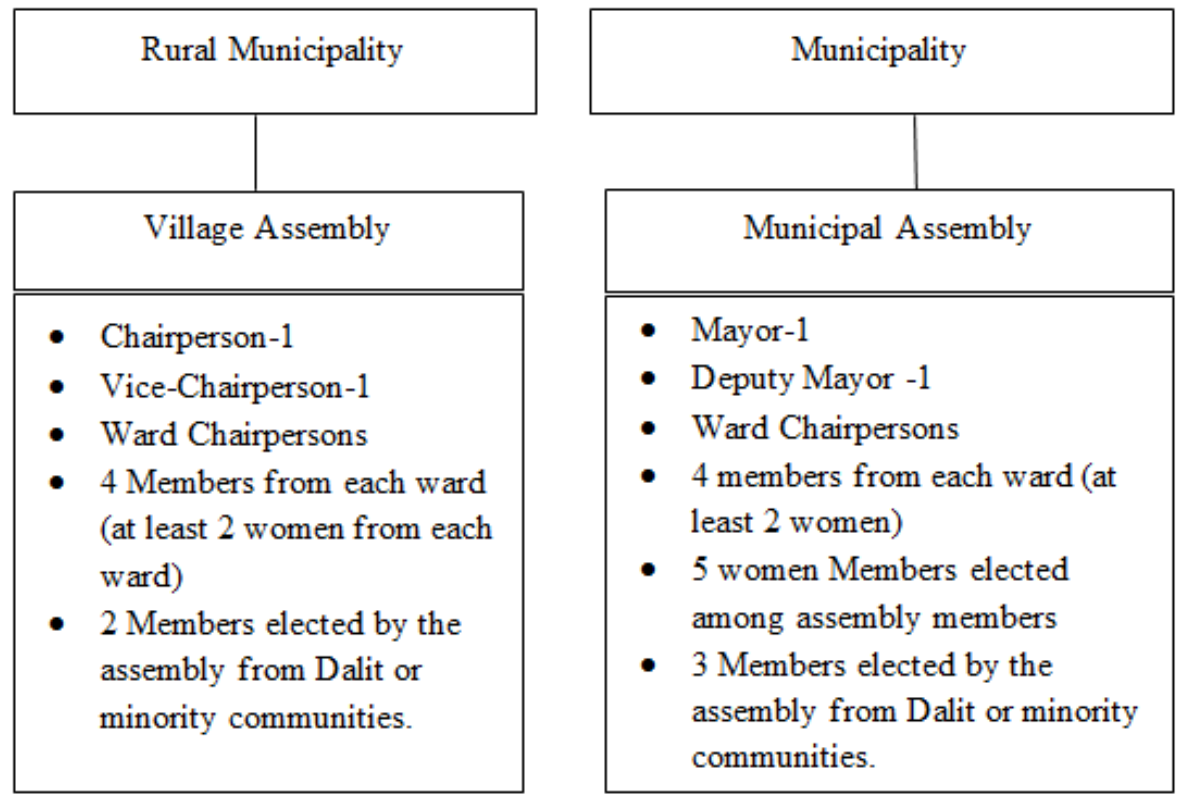

FIGURE 1. The composition of village assembly and municipal assembly at local level Source: (Nepal Law Commission, 2019)

The municipal assembly comprises of a Mayor, Deputy Mayor, Ward chairpersons and 4 members from each ward who are directly elected by the people through one person one vote, first past the post electoral system. The remaining members are 5 women members elected by the assembly amongst themselves and 3 members belonging to Dalit or minority community (Nepal Law Commission, 2019). The village assembly consists of Chairperson, Vice-chairperson,
Ward chairpersons, 4 members from each ward with at least 2 women who are directly elected. The remaining 2 members are from Dalit or minority communities elected by the assembly.

The Village Executive and Municipal Executive exercise the local executive power. A Municipal Executive consists of Mayor, Deputy-Mayor, Ward Chairpersons and 8 members within which 5 are women elected from Municipal Assem- 
bly and 3 are from Dalit and minority communities. A Village Executive consists of Chairperson, Vice-chairperson, Ward chairpersons and 6 members who include at least 4

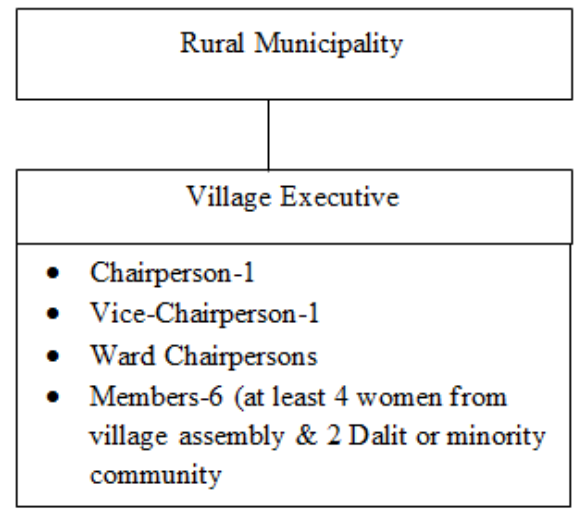

women from the village assembly and 2 from Dalit or minority communities. Figure 2 below, shows composition of the Municipal and Village Executives.

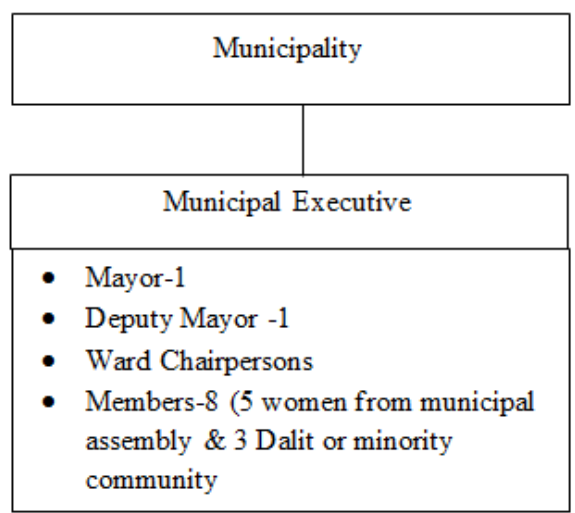

FIGURE 2. The composition of village executive and municipal executive at local level (Source: (Nepal Law Commission, 2019)

The constitutional provision requires each political party to nominate at least 1-woman candidate for either chairperson or deputy chairperson for the election of local bodies (Government of Nepal, 2015). This means if a political party has a man candidate for a mayor of the municipality, the candidate for deputy mayor has to be a woman and vice-versa. This provision has maximized the chances of women representation in at least 1 of the top leadership positions at local levels.

Such steps of affirmative action have resulted to record numbers of women representatives being elected. Especially, significant representation was achieved from women coming from marginalized communities (The Asia Foundation, 2019; Election Commission, 2019). 14,352 women representatives were elected out of the total of 35,041 , elected representatives on the local election of 2017. The share of elected women representatives therefore reaching 40.96 percent (Election Commission, 2019). This certainly bodes well as a foundation to work on for women empowerment, gender equality and social inclusion.

Emergence of aforementioned formal leaders and growing number of community-based organizations has created foundations for combined efforts of local communities and governments to fight poverty and inequality. Government of Nepal has identified cooperatives sector as one of three pillars of Nepalese economy alongside the public and private sectors. They are in operation under Cooperatives Act 2017 enacted under clause 1 of Article 296 of the Constitution of Nepal (Nepal Law Commission, 2018). Strengths of cooperatives lies in being community-based organizations having huge reach among grassroots of Nepalese communities. The 15th periodic plan of the National Planning Commission (NPC) from $2019 / 20$ to $2023 / 24$ puts high priority on development of this sector for creating sustainable community development through promotion of entrepreneurship, creation of income generating activities and activities for social transformation. Out of huge reach of 6.3 million members in various types of cooperatives across Nepal, $52 \%$ are women and $40 \%$ are in the steering committees (National Planning Commission, 2019). In order to achieve the targets of Sustainable Development Goals (SDGs) too, CBOs such as cooperatives have been identified to play a vital role alongside efforts of local and central governments. Hence, Local endogenous efforts going in line with national agendas make it more effective in fight against eradicating poverty and achieving the SDGs.

\section{DISCUSSION}

From the review of literature and document analysis, two main characteristics of Nepalese communities have been identified. First, Nepalese communities are socioeconomically and culturally heterogeneous in nature and that heterogeneity has its effects on social capital formation and growth. Heterogeneity limiting social capital formulation and growth also has its consequences in effective participation. Second, lack of meaningful interaction between the marginalized groups in rural communities and the public institutions have limited their access to services and potential for growth and development. However, the election of local bodies in 2017 and emergence of local leaders has provided a new platform for interaction which could lead to utilization of networks and local assets for community development.

Regarding heterogeneity and its effects on social capital, it was found that Nepalese communities are characterized by the presence of few predominant castes and ethnicities ex- 
ercising more power over fragmented minorities. Representation of Dalits and other marginalized groups in public institution has been minimal until recently. The dominant groups want to tighten their grips on state services and continue their exercise of power by establishing strong bonds with members from similar groups. Whereas, marginalized and minorities develop bonding to protect themselves from domination and voice their discontent. Hence, it can be said that there are rich ties of bonding social capital but lack in bridging social capital. However, for growth and development through mobilization of communities, bridging social capital needs to be developed (Gittell \& Vidal, 1998; Mathie \& Cunningham, 2003; Woolcock \& Narayan, 2000). Therefore, strategies to building social ties beyond one's own group or community must be implemented. Some such measures to overcome the barriers for building stocks of social capital are institutionally arranged in the constitution, while others need future intervention from policymakers. The Constitution of Nepal 2015 has guaranteed provisions of one-third women representation in parliament. Women also have got a meaningful share of representation in local levels. Hence, foundations have been laid towards addressing the issue of gender equity. The election system being mixed and $40 \%$ of the parliamentarians being elected based on proportional representation has assured that even members from marginalized groups, different castes and ethnicities from diverse communities have their representation in policy-making bodies. New federal structure and local governance system has provided ground for them to make their voices heard and initiate changes for social inclusion and justice.

Besides institutional arrangements of affirmative action, existing CBOs such as cooperatives, youth and women groups etc. can be an effective tool for mobilizing the communities. Furthermore, women's cooperatives, saving and credit cooperatives etc have large resources and network from members of different social groups. These CBOs provide an effective avenue for community members to engage in community activities. Rather than creating new organizations, building on these existing organizations is cheaper and effective as they already have trust and legitimization from local people (Chaskin et al., 2001; Green, 2014). Co-production strategies can also foster more cooperation among communities and public institutions. Such strategies can be used for building public spaces that foster interaction such as public parks, common places of worships etc. which can also contribute in connecting the various social groups (Krishna, 2002).

The second characteristic of marginalization of rural areas and minority groups from state services and public institutions has adversely affected the development of communities in terms of economic outcome and livelihood opportunities. It has also deprived them from access to basic services. However, with new local governance system in place with elected representatives at local levels, these groups can be brought into the mainstream. Local leadership can play the role of a 'mediating agency' between communities and state institutions and organize them for community change. In this way, from 'objects' of change people could become 'agents' of change (Green \& Haines, 2015; Mathie \& Cunningham, 2003). Capacity development of formal leaders and leadership development of local leaders is important for transformative change (Chaskin et al., 2001).

The 2017 election of local levels has created a large number of new formal leaders. Especially, among women and those coming from Dalit and minority communities as a result of affirmative action. Besides these leaders, informal local community leaders or youth leaders can be accessed to generate influence over the communities. However, caution must be taken to ensure that these leaders do not indulge in corruption or develop 'clientelism' i.e. in order to continue their exercise of power and influence, they provide benefits to people in their network and make them dependent on them (Mansuri \& Rao, 2012). Their influence however, cannot be ignored. Hence, making wise use of local leaders is an important strategy to build bridging and linking social capital in communities.

Social ties and networks are especially important in communities that are lacking in other forms of assets such as physical assets and financial capitals. Social capital makes those assets and capital accessible through community action (Green \& Haines, 2015). Hence through linking social capital, assets based endogenous development initiatives can create viable livelihood and economic opportunities. Assets based community development approach emphasizes common interests that promote mutual cooperation and therefore forms a basis for community mobilization. It can be used as a tool for an application of social capital to mobilize community and create productive outcomes (Mathie \& Cunningham, 2003). Such endogenous process promoted with facilitating role from external agencies and actors lead to more sustainable outcome. Communities can identify local assets in the form of goods or services such as agriculture products, herbs and sites with tourism potential etc. where value addition is possible to generate income. By enhancing the bridging and linking social capital, processing and marketing techniques can be learnt and products and services can yield value added income. Such micro 
level initiatives should not be overlooked as small changes multiply and have transformational value to have impact on macro level.

\section{CONCLUSION}

This research described the local governance systems and socio-economic realities of communities in Nepal through the perspectives of social capital and assets based community development approaches. By contextualizing these alternative development perspectives with the local systems and settings in Nepal, it identified 2 distinct characteristics 1) Nepalese communities are socio-economically heterogeneous and that affects social capital accumulation and generating effective participation and 2) Marginalized groups and rural communities need effective interaction with mainstream public institutions for balanced growth and development with the help of local leadership.

In order to address the problem of heterogeneity limiting participation and resulting to a lack of accumulation of social capital, institutional measures such as affirmative action and inclusive representation guaranteed by the Constitution of Nepal 2015 were identified. These measures serve as platforms for building bridging social capital and creating inclusive and strong public institutions. There are such positive changes in institutional arrangements. However, to promote meaningful participation in its true sense, barriers such as practice of untouchability through caste system and other ill social practices must be eliminated through effective implementation of these measures by public institutions.

On the other hand, to generate economic impacts for pros- perity and growth of rural and marginalized communities, available local assets and networks could be activated by the local leadership by playing the role of a mediating agency between state institutions and the communities. Furthermore, the local governments by working closely with the CBOs working in the grassroot communities could organize and mobilize the people for economic as well as social transformation by working towards eradication of poverty and achievement of SDGs.

The new system of local governance has only been in practice in Nepal since 2017. It is on its learning stages and time is required for swift transition, for it to work efficiently by exercising the powers and duties provided to it by the constitution.

\section{LIMITATIONS AND RECOMMENDATIONS}

The findings of this research are based upon literature survey and analysis of documents. Hence, its scope is limited to draw general conclusions on the application of alternative development theories in local governance systems of Nepal. It has identified the foundations laid by the new constitution and systems in place in which they could operate. However, to generate further conclusive evidences and practical implications of this research, further research such as case study research on local governance of some local governments could build up on the findings of this research by gathering more empirical evidence. Additionally, some of the criticisms the social capital and assets based community development approaches have faced regarding their limitations of addressing clientelism and corruption among leaders need more clarification through further research.

\section{REFERENCES}

Aldrich, D. P., \& Meyer, M. A. (2015). Social capital and community resilience. American Behavioral Scientist, 59(2), 254-269. doi:https://doi.org/10.1177/0002764214550299

Alesina, A., \& Ferrara, E. L. (2005). Ethnic diversity and economic performance. Journal of Economic Literature, 43(3), 762-800. doi:https://doi.org/10.1257/002205105774431243

Alesina, A., \& La Ferrara, E. (2000). Participation in heterogeneous communities. The Quarterly Journal of Economics, 115(3), 847-904. doi:https://doi.org/10.1162/003355300554935

Bowen, G. A., et al. (2009). Document analysis as a qualitative research method. Qualitative Research Journal, 9(2), 27-40. doi:https://doi.org/10.3316/qrj0902027

Burkart, C., Wakolbinger, T., \& Toyasaki, F. (2018). Funds allocation in NPOs: The role of administrative cost ratios. Central European Journal of Operations Research, 26(2), 307-330. doi:https://doi.org/10.1007/s10100-017-0512-9

Central Bureau of Statiscs. (2014). Population monograph of Nepal 2014. Retrieved from https://bit. ly/2N1JOgv

Central Bureau of Statiscs. (2019). Population atlas of Nepal. Retrieved from https://bit. ly/3hwCdEN

Chambers, R. (1983). Rural development: Putting the last first. London, UK: Pearson.

Chaskin, R., Brown, P., Venkatesh, S., \& Vidal, A. (2001). Building community capacity. New York, NY: Walter De Gruyter.

Claridge, T. (2018). Functions of social capital bonding, bridging, linking. Retrieved from https://bit. 1y/3e8pExt 
Coffé, H., \& Geys, B. (2006). Community heterogeneity: A burden for the creation of social capital? Social Science Quarterly, 87(5), 1053-1072. doi:https://doi.org/10.1111/j.1540-6237.2006.00415.x

Coleman, J. S. (1988). Social capital and the development of human capital. American Journal of Sociology, 94(5), 95-120. doi:https://doi.org/10.1086/228943

Cuyugan, A. B. S., Agus, G. E., Dasig Jr., D. D., Nidea, M. A., Claricia, E. E., Taduyo, M. A. B., \& Camacho, E. J. (2017). In aid of community policy and framework development: A sustainable integrated community advancement program. Journal of Advanced Research in Social Sciences and Humanities, 2(2), 87-95. doi:https://doi.org/10.26500/jarssh-02-2017 $-0202$

Election Commission. (2019). Gender based elected representative's numerical description. Retrieved from https : //bit . Iy/ $37 \mathrm{CS} 7 \mathrm{c} 4$

Escobar, A. (1995). Encountering development: the making and unmaking of the third world.princeton. New Jersy, NJ: Princeton University Press.

Fukuyama, F. (2002). Social capital and development: The coming agenda. SAIS Review, 22(1), 23-37. doi:https://doi.org/ 10.1353/sais.2002.0009

Gittell, R., \& Vidal, A. (1998). Community organizing: Building social capital as a development strategy. California, CA: Sage Publications.

Government of Nepal. (2015). The constitution of Nepal, Kathmandu: Law books management committee. Retrieved from https://bit.ly/3fsltgf

Green, G. P. (2014). Community asset mapping and survey. In R. Philips, and R. H. Mittman (Eds.), An introduction to community development. New York, NY: Routledge.

Green, G. P., \& Haines, A. (2015). Asset building \& community development. New York, NY: Sage Publications.

Haines, A. (2014). Asset-based community development. In R. Philips, and R. H. Mittman (Eds.), An introduction to community development. London, UK: Routledge.

Kretzman, J., \& McKnight, J. (1993). Building communities from inside out. Chicago, IL: ACTA Publications.

Krishna, A. (2002). Active social capital: Tracing the roots of development and democracy. New York, NY: Columbia University Press.

Lawoti, M., \& Pahari, A. K. (2009). The maoist insurgency in Nepal: Revolution in the twenty-first century. New York, NY: Routledge.

Lin, N. (2000). Inequality in social capital. Contemporary Sociology, 29(6), 785-795. doi:https://doi.org/10.2307/2654086

Mansuri, G., \& Rao, V. (2004). Community-based and-driven development: A critical review. The World Bank Research Observer, 19(1), 1-39. doi:https://doi.org/10.1093/wbro/lkh012

Mansuri, G., \& Rao, V. (2012). Localizing development: Does participation work? Washington, D.C: WA: The World Bank.

Marks, M. B. (2008). A theoretical and empirical investigation of co-production interventions for involuntary youth in the child welfare and juvenile justice systems. New York, NY: State University Press.

Mathie, A., \& Cunningham, G. (2003). From clients to citizens: Asset-based community development as a strategy for community-driven development. Development in Practice, 13(5), 474-486. doi:https://doi.org/10.1080/ 0961452032000125857

Minamoto, Y. (2010). Social capital and livelihood recovery: Post-tsunami Sri Lanka as a case. Disaster Prevention and Management: An International Journal, 15(9), 548-564. doi:https://doi.org/10.1108/09653561011091887

Ministry of Finance. (2019). Economic survey 2018/19 Kathmandu: Government of Nepal. Retrieved from https : //bit . ly/ 37yaU8E

National Planning Commission. (2019). 15th plan approach paper 2019/20-2023/24 Nepal. Retrieved from https:// bit. 1y/2AKNXDO

Nepal Law Commission. (2018). Cooperatives act 2017. Retrieved from https : //bit.1y/2YFxcRV

Nepal Law Commission. (2019). Constitution of Nepal. Retrieved from https://bit.1y/3e3Jv0h

Nikkhah, H. A., \& Redzuan, M. (2009). Participation as a medium of empowerment in community development. European Journal of Social Sciences, 11(1), 170-176.

Punluekdej, T., \& Srisorn, W. (2017). The development pattern of community enterprise to become strengthened: A case study of Nakhon Cowboy, Bangkok Noi, Bangkok, Thailand. International Journal of Humanities, Arts and Social Sciences, 
3(3), 129-141. doi:https://doi.org/10.20469/ijhss.3.20005-3

Putnam, R. D. (2000). Bowling alone: The collapse and revival of American community. New York, NY: Simon and Schuster.

Ross, H., Baldwin, C., \& Carter, R. (2016). Subtle implications: public participation versus community engagement in environmental decision-making. Australian Journal of Environmental Management, 23(2), 123-129. doi:https://doi.org/ 10.1080/14486563.2016.1194588

The Asia Foundation. (2019). Nepal's locally elected women representatives: Exploratory study of needs and capacities. Retrieved from https://bit.1y/2UQtcwA

United Nations. (2018). List of least developed countries. Retrieved from https://bit.ly/2Ceg5iu

Woolcock, M. (2001). The place of social capital in understanding social and economic outcomes. Canadian Journal of Policy Research, 2(1), 11-17.

Woolcock, M., \& Narayan, D. (2000). Capital social: Implicaciones para la teoría, la investigación y las políticas sobre desarrollo. World Bank Research Observer, 15(2), 225-249. doi:https://doi.org/10.1093/wbro/15.2.225 